\title{
ARLTS1 polymorphisms and basal cell carcinoma of the skin
}

\author{
Xuchen Li', Andreas Gast', Peter Rudnai', Eugene Gurzau ${ }^{3}$, Kvetoslava Koppova ${ }^{4}$, Kari Hemminki ${ }^{1,5}$, Rajiv Kumar' \\ Division of Molecular Genetic Epidemiology, German Cancer Research Center, Heidelberg, Germany, 2National Institute of Environmental Health, Budapest, Hungary, \\ ${ }^{3}$ Environmental Health Center, Cluj, Romania, 4 State Health Institute, Banska Bystrica, Slovakia, 5 Center for Family Medicine, Karolinska Institute, Huddinge, Sweden
}

Key words: polymorphisms, ARLTS1, skin cancer

Corresponding author: Rajiv Kumar, Division of Molecular Genetic Epidemiology, German Cancer Research Center, Im Neuenheimer Feld 580, 69120 Heidelberg, Germany, phone +4962 214218 06, fax +4962 21421810 , Email: r.kumar@dkfz.de

Submitted: 7 February 2007

Accepted: 9 February 2007

\begin{abstract}
Polymorphisms in the ARLTS1 gene, a member of the Ras super-family, have been associated with susceptibility in different cancer types. The involvement of the gene in apoptotic signalling motivated us to study the role of ARLTS 1 polymorphic variations in basal cell carcinoma of the skin (BCC). In a case-control study, 529 cases diagnosed with BCC and 533 controls from Hungary, Romania and Slovakia were genotyped for the S99S (297G >A), P131L (392C>T), L132L (396G >C), C148R (442T>C) and W149X (446G>A) polymorphisms in the ARLTS 1 gene. No significant association between any of the single nucleotide polymorphisms (SNP) and risk of $\mathrm{BCC}$ (S99S, odds ratio (OR) 0.96, 95\% confidence interval (Cl) 0.60-1.53; P131L, OR $1.3195 \% \mathrm{Cl}$ 0.74-2.31; L132L, OR 0.50, 95\%Cl 0.02-7.07; C148R, OR 0.50,95\%Cl 0.69-1.18; and W1 49X, OR 1.01, $95 \% \mathrm{Cl}$ 0.37-2.79) was detected. Furthermore, no significant difference in the distribution of haplotypes due to five polymorphisms in the ARLTS1 gene was found between the BCC cases and controls. Our data rule out an association between variants in ARLTS1 and risk of BCC in the investigated population.
\end{abstract}

\section{Introduction}

Basal cell carcinoma $(\mathrm{BCC})$ is the most common skin neoplasm, accounting for over $75 \%$ of all skin cancers $[1,2]$. Though BCC occurs mainly sporadically, multiple tumours with an early onset are associated with rare genetic disorders like Gorlin syndrome and xeroderma pigmentosum [3]. BCC tumours grow slowly and seldom metastasize; the recurrence and tissue destruction cause extensive morbidity [4]. UV radiation is a major environmental factor associated with increased incidence of $B C C$ due to increased leisure sun exposure $[5,6]$. In specific instances arsenic exposure has also been associated with increased risk of non-melanoma skin cancers, including BCC [7]. The aetiology of BCC ultimately involves an interplay between genetic and environmental factors like UV radiation.

BCC mainly originates through UV-mediated DNA damage. The consequent mutations in the critical genes result in growth advantage to the affected cells leading to clonal expansion. Mechanistically apoptosis prevents carcinogenesis by eliminating cells with excessive damage that escape the DNA repair machinery [8]. We hypothesized that variants in the genes involved in apoptosis can potentially modulate disease susceptibility. Genetic variants in critical genes can potentially modify susceptibility to BCC through subtle influences on critical cellular processes like DNA repair, cell cycle and apoptosis. 
ADP-ribosylation factor-like tumour suppressor gene 1 (ARLTS1) is a member of the Ras superfamily, involved in apoptotic signalling. Previously this gene has been suggested to be associated with susceptibility of multiple cancer types [9]. Therefore in this study we investigated the role of variants in the ARLTS I gene on BCC susceptibility in cases and matching controls recruited from areas of Hungary, Romania and Slovakia.

\section{Materials and methods}

Study population: Cases and controls were recruited as part of a large study on risk of various cancers due to environmental exposures in Hungary, Romania and Slovakia between 2002 and 2004 . The recruitment was carried out in the counties of Bacs, Bekes, Csongrad and Jasz-Nagykun-Szolnok in Hungay; Bihor and Arad in Romania; and Banska Bistrica and Nitra in Slovakia. 529 skin cancer cases, mean age 63.5 (median 66; range 2-85), were invited on the basis of histopathological examinations by pathologists. 533 hospitalbased controls, mean age 60 (median 61; range 28-82), were included in the study, subject to fulfilment of a set of criteria. Those controls included general surgery, orthopaedic and trauma patients with conditions such as appendicitis, abdominal hernias, duodenal ulcers, cholelithiasis and fractures; patients with malignant tumours, diabetes and cardiovascular diseases were excluded. They were also broadly matched with cases for age, gender, country of residence and ethnicity.

\section{Genotyping}

DNA was isolated from blood samples from cases and controls using Qiagen mini-preparation kits and genotyped for variants in the ARLTS 1 gene by direct DNA sequencing. A 237-bp product containing exon 2 of the ARLTS 1 gene was amplified and sequenced bidirectionally using primers 5'-GAT ATC CTC GTG TAC GTG CTG (forward) and 5'-GAG CAA AGA TAT GCT GCT CTG T (reverse). The conditions used for $P C R$ and sequencing reactions were as described previously [10]. The sequencing reaction products were analyzed on an $A B I$ prism 3100 genetic analyzer and primary sequence data checked using sequence analysis software (Applied Biosystem, Forster City, CA).

\section{Statistical Analysis}

Genotype frequencies in cases and controls for all SNPs were tested for deviation from the Hardy-Weinberg equilibrium using chi^ 2 or Fisher's exact test. Age, gender and nationality adjusted odds ratio (OR), 95\% confidence intervals (Cl) for risk of BCC associated with each genotype and variant allele of five SNPs were calculated with logistic regression using SAS version 9.1 (SAS Institute, Cary, NC). Relation between genotype and $\mathrm{BCC}$ risk were summarized as global P-values. Linkage disequilibrium was calculated with Haplotype software (www.broad.mit.edu/mpg/haploview/documentation.php). Power calculation was carried out using Power and Sample Size calculation software version 2.1.31.

\section{Results}

The genotyping of a 237 bp-fragment of exon 2 of the ARLTS 1 resulted in detection of 5 single nucleotide polymorphisms in 529 BCC cases and 533 controls. The sample size of this study was sufficient to detect under the dominant model the effect of polymorphisms with a minor allele frequency higher than 0.2 and an associated $\mathrm{OR}$ equal to or higher than 1.5 with a power of $80 \%$. Two SNPs (297G $>$ A and $396 \mathrm{G}>\mathrm{C}$ ) were synonymous, 2 non-synonymous SNPs (392 C>T and $442 \mathrm{~T}>\mathrm{C}$ ) resulted in $\mathrm{P1} 31 \mathrm{~L}$ and $\mathrm{C} 148 \mathrm{R}$ amino acid changes, and the G446A SNP resulted in W149X truncating polymorphism. Genotype distribution for all five polymorphisms based on allele frequencies were in accordance with Hardy-Weinberg equilibrium. The minor allele frequencies for five polymorphisms ranged from 0.01 (396G >C) to 0.45 (442 T>C) (Table 1).

$\mathrm{OR}$ and corresponding $95 \% \mathrm{Cl}$ intervals associated with each genotype and variant allele are detailed in Table 1. For none of the five polymorphisms was any statistical significant difference observed for genotype and allele frequencies between BCC cases and controls. The analysis of resultant haplotypes due to 5 SNPs in the gene showed presence of 8 out of 32 possible haplotypes. In controls, however, only 4 haplotypes were detected. The major haplotype GCGTG consisted of common alleles of all 5 polymorphisms and together with GCGCG haplotype accounted for over 90 percent of all cases and controls. However, no differences in distribution of haplotypes between cases and controls were observed (Table 2). Linkage disequilibrium was observed between $392 \mathrm{C}>\mathrm{T}$ and 442T>C $\left(\mathrm{D}^{\prime}=1.0\right)$, and between $442 \mathrm{~T}>\mathrm{C}$ and $446 \mathrm{G}>\mathrm{A}\left(\mathrm{D}^{\prime}=1.0\right)$ (Fig. 1). However, the $r^{\wedge} 2$ values for these linkages were only 0.02 and 0.007. The variant T-allele for the P131L (392C > T) polymorphism occurred only in the presence of one or two T-alleles of the C148R (442T>C) polymorphism. Similarly, A-allele for the W149X (446G > A) polymorphism was detected only in the presence of the T-allele of the C148T (442T>C) polymorphism. Consequently, the variant allele for the W149X (446G>A) polymorphism occurred together only with the common allele genotype of the P131L (392C>T) polymorphism. 
Table 1. Genotype and allele distribution of variants in the ARLTS1 gene in BCC cases and controls

\begin{tabular}{lllll}
\hline Genotype/Allele & Cases* & Controls & OR (95\%Cl) & P-value \\
\hline S99S $(297 G>A)$ & $487(92.2)$ & $490(91.9)$ & 1.0 (referent) & \\
GG & $41(7.7)$ & $43(8.1)$ & $1.1(0.7-1.7)$ & $0.81^{* *}$ \\
\hline GA & $1015(96.1)$ & $1023(96.0)$ & 1.0 (referent) & 0.81 \\
\hline G-allele & $41(3.9)$ & $43(4.0)$ & $1.1(0.7-1.6)$ & 1.0 (referent) \\
\hline A-allele & $496(93.9)$ & $508(95.3)$ & $1.3(0.8-2.3)$ & 0.30 \\
\hline CT 31 L $(392 C>$ T) & $32(6.1)$ & $25(4.7)$ & 1.0 (referent) & 0.31 \\
\hline C-allele & $1024(97.0)$ & $1041(97.7)$ & $1.3(0.8-2.3)$ & \\
\hline T-allele & $32(3.0)$ & $25(2.3)$ & & \\
\hline
\end{tabular}

L132L (396G >C)

\begin{tabular}{lllll} 
GG & $527(99.8)$ & $531(99.6)$ & 1.0 (referent) & \\
\hline$G C$ & $1(0.2)$ & $2(0.4)$ & $0.4(0.1-4.0)$ & 0.40 \\
\hline G-allele & $1055(99.9)$ & $1064(99.8)$ & 1.0 (referent) & \\
\hline C-allele & $1(0.1)$ & $2(0.2)$ & $0.4(0.1-4.0)$ & 0.40
\end{tabular}

C148R $(442 \mathrm{~T}>\mathrm{C})$

\begin{tabular}{lllll} 
TT & $165(31.3)$ & $155(29.1)$ & 1.0 (referent) & \\
\hline TC & $250(47.4)$ & $258(48.4)$ & $0.9(0.7-1.2)$ & 0.64 \\
\hline CC & $113(21.0)$ & $120(22.5)$ & $0.9(0.6-1.2)$ & 1.0 (referent) \\
\hline T-allele & $580(54.9)$ & $568(53.3)$ & $0.9(0.8-1.1)$ & 0.36 \\
\hline C-allele & $476(45.1)$ & $498(46.7)$ & &
\end{tabular}

W1 49X (446G>A)

\begin{tabular}{lllll} 
GG & $519(98.3)$ & $524(98.3)$ & 1.0 (referent) & \\
\hline GA & $9(1.7)$ & $9(1.7)$ & $1.5(0.6-4.0)$ & 0.41 \\
\hline G-allele & $1047(99.2)$ & $1057(99.2)$ & 1.0 (referent) & \\
\hline A-allele & $9(0.8)$ & $9(0.8)$ & $1.5(0.5-3.5)$ & 0.41
\end{tabular}

*The number of cases and controls included in the study was 529 and 533, respectively. The sequencing for genotyping failed for one sample among cases. ${ }^{* *}$ Global P-values calculated from $\mathrm{chi}^{\wedge} 2$ test for genotype as a single event and allele effects were adjusted for age, gender and nationality.

\section{Discussion}

In this study we evaluated the association of polymorphisms in the ARLTS1 gene with modulation of $B C C$ risk. Our results showed that none of the coding sequence polymorphisms in the ARLTS1 gene was associated with risk modulation of BCC. While data showed linkage disequilibrium between three of the polymorphisms, the resultant haplotypes did not show differential distribution between cases and controls. In the initial study the truncating W149X (446G >A) polymorphism in the ARLTS1 gene was reported to be associated with increased risk of familial breast cancer; in latter studies C148R (442T>C) polymorphism in the gene was also associated with marginal risk of familial breast cancer and melanoma [9-11]. At the same time 
Table 2. Distribution of major haplotypes in the ARLTS1 gene in BCC cases and controls

\begin{tabular}{llllc}
\hline Haplotype & Cases & Controls & OR (95\%Cl) & P-value* $^{*}$ \\
\hline GCGTG & $249(46.7)$ & $249(47.0)$ & 1.0 (referent) & 0.90 \\
\hline GCGTA & $4(0.8)$ & $5(1.0)$ & $0.8(0.2-3.0)$ & \\
\hline GCGCG & $246(46.2)$ & $238(45.0)$ & $1.0(0.8-1.3)$ & \\
\hline GTGTG & $12(2.3)$ & $16(3.0)$ & $0.8(0.3-1.6)$ & \\
\hline ACGTG & $18(3.4)$ & $21(4.0)$ & $0.9(0.4-1.6)$ & \\
\hline
\end{tabular}

*Global P-value for haplotype effect calculated from chi ^ 2 test.

\begin{tabular}{|c|c|c|c|c|}
\hline $297 G>$ & $392 C>T$ & $442 \mathrm{~T}>\mathrm{C}$ & $446 G>A$ & \\
\hline \multirow[t]{4}{*}{1} & 0.018 & 0.769 & 0.033 & $297 G>A$ \\
\hline & 1 & 1 & 1 & $392 C>T$ \\
\hline & & 1 & 1 & $442 \mathrm{~T}>\mathrm{C}$ \\
\hline & & & 1 & $446 G>A$ \\
\hline
\end{tabular}

Fig. 1. Linkage disequilibrium ( $D^{\prime}$ ) between polymorphisms in the ARLTS 1 gene

no association was observed with risk of various sporadic cancers [12-14].

ARLTS1 is a member of the Ras superfamily and resides on chromosome 13q14, which is frequently deleted in a variety of haematopoietic and solid tumours $[15,16]$. Promoter hypermethylation of ARLTS1 and consequent down regulation of expression has been reported in B-cell chronic lymphocytic leukaemia and lung cancers [9]. Moreover the restoration of ARLTS1 in negative ovarian cells has been reported to reduce tumorigenic potential in nude mice. Functionally, the W149X polymorphism has been shown to induce apoptosis in the infected cells at a significantly reduced level rather than complete ablation [17]. This was hypothesized as the potential reason for retention of a rather drastic polymorphism in the population and could probably also explain the lack of associations with many cancer types including the BCC in the present study.

In an earlier investigation on the same study population we observed an association of reduced risk of BCC with a variant allele of the XRCC3 gene and a gender-specific increased risk due to a variant in the NBS1 genes [18]. Both the XRCC3 and NBS1 genes are involved in the repair of DNA double strand breaks. While DNA repair capacity is potentially a critical determinant of risk of BCC, the results from this study suggest that influence of ARLTS 1 variants on apoptosis, if any, does not impact the risk of BCC, which is one of the largest cancer types. However, despite a large sample size, the power of our study could be limited for detection of risk associated with polymorphisms with minor allele frequencies less than 10 percent. Moreover, association studies in general are linked with poor reproducibility [19].

In conclusion, our data show lack of an association between polymorphisms and resultant haplotypes in the ARLTS1 gene and risk of BCC. The hypothesis of association of multiple cancer types with ARLTS 1 variants is not supported by the data in this study.

\section{References}

1. Bowden GT. Prevention of non-melanoma skin cancer by targeting ultraviolet-B-light signalling. Nat Rev Cancer 2004; 4: 23-35.

2. Tsai KY, Tsao H. The genetics of skin cancer. Am J Med Genet C Semin Med Genet 2004; 131 C: 82-92.

3. Tsao H. Genetics of nonmelanoma skin cancer. Arch Dermatol 2001; 137: 1486-1492.

4. Green CL, Khavari PA. Targets for molecular therapy of skin cancer. Semin Cancer Biol 2004; 14: 63-9.

5. Lovatt TJ, Lear JT, Bastrilles J, Wong C, Griffiths CE, Samarasinghe V, Roebuck J, Ramachandran S, Smith AG, Jones PW, Fryer AA, Strange RC. Associations between ultraviolet radiation, basal cell carcinoma site and histology, host characteristics, and rate of development of further tumors. J Am Acad Dermatol 2005; 52: 468-473.

6. de Gruijl FR, van Kranen HJ, Mullenders LH. UV-induced DNA damage, repair, mutations and oncogenic pathways in skin cancer. J Photochem Photobiol B 2001; 63: 19-27.

7. Karagas MR, Stukel TA, Morris JS, Tosteson TD, Weiss JE, Spencer SK, Greenberg ER. Skin cancer risk in relation to toenail arsenic concentrations in a US population-based case-control study. Am J Epidemiol 2001; 153: 559-565.

8. Brown JM, Attardi LD. The role of apoptosis in cancer development and treatment response. Nat Rev Cancer 2005; 5: $231-237$.

9. Calin GA, Trapasso F, Shimizu M, Dumitru CD, Yendamuri S, Godwin AK, Ferracin M, Bernardi G, Chatterjee D, Baldassarre G, Rattan S, Alder H, Mabuchi H, Shiraishi T, Hansen LL, Overgaard J, Herlea V, Mauro FR, Dighiero G, Movsas B, Rassenti L, Kipps T, Baffa R, Fusco A, Mori M, Russo G, Liu CG, Neuberg D, Bullrich F, Negrini M, Croce CM. Familial cancer associated with a polymorphism in ARLTS1. N Engl J Med 2005; 352: 1667-1676. 
10. Frank B, Hemminki K, Meindl A, Wappenschmidt B, Klaes R, Schmutzler RK, Untch M, Bugert P, Bartram CR, Burwinkel B. Association of the ARLTS1 Cys 148Arg variant with familial breast cancer risk. Int J Cancer 2006; 1 18: 2505-2508.

11. Frank B, Meyer P, Boettger MB, Hemminki K, Stapelmann H, Gast A, Schmitt C, Kumar R, Sergi C, Burwinkel B. ARLTS1 variants and melanoma risk. Int J Cancer 2006; 1 19: 1736-1737.

12. Frank B, Hemminki K, Brenner H, Hoffmeister M, Chang-Claude J, Burwinkel B. ARLTS1 variants and risk of colorectal cancer. Cancer Lett 2006; 244: 172-175.

13. Sellick GS, Catovsky D, Houlston RS. Relationship between ARLTS1 polymorphisms and risk of chronic lymphocytic leukemia. Leuk Res 2006; 30: 1573-1576.

14. Masojc B, Mierzejewski M, Cybulski C, van de Wetering T, Debniak T, Gorski B, Jaworowska E, Tarnowska C, Lenner M, Scott RJ, Lubinski J. Cancer Familial Aggregation (CFA) and G446A polymorphism in ARLTS1 gene. Breast Cancer Res Treat 2006; 99: 59-62.

15. Bullrich F, Fujii H, Calin G, Mabuchi $H$, Negrini M, Pekarsky $Y$, Rassenti L, Alder H, Reed JC, Keating MJ, Kipps TJ, Croce CM. Characterization of the 13q14 tumor suppressor locus in CLL: identification of ALTI, an alternative splice variant of the LEU2 gene. Cancer Res 2001; 61: 6640-6648.

16. Mabuchi H, Fujii H, Calin G, Alder H, Negrini M, Rassenti L, Kipps TJ, Bullrich F, Croce CM. Cloning and characterization of CLLD6, CLLD7, and CLLD8, novel candidate genes for leukemogenesis at chromosome 13q14, a region commonly deleted in B-cell chronic lymphocytic leukemia. Cancer Res $2001 ; 61: 2870-2877$.

17. Petrocca F, Iliopoulos D, Qin HR, Nicoloso MS, Yendamuri S, Wojcik SE, Shimizu M, Di Leva G, Vecchione A, Trapasso F, Godwin AK, Negrini M, Calin GA, Croce CM. Alterations of the tumor suppressor gene ARLTS1 in ovarian cancer. Cancer Res 2006; 66: 10287-10291.

18. Thirumaran RK, Bermejo JL, Rudnai P, Gurzau E, Koppova K, Goessler W, Vahter M, Leonardi GS, Clemens F, Fletcher T, Hemminki K, Kumar R. Single nucleotide polymorphisms in DNA repair genes and basal cell carcinoma of skin. Carcinogenesis 2006; 27: 1676-1681.

19. Pharoah PD, Dunning AM, Ponder BA, Easton DF. Association studies for finding cancer-susceptibility genetic variants. Nat Rev Cancer 2004; 4: 850-860. 